\section{The real cause of Ethiopia's problems}

SIR-Constructive analysis and critical review by the scientific community of possible interventions to avoid future disasters in the drought-stricken African Sahel is the least that can be asked. John R. Krebs and Malcolm J. Coe ${ }^{1}$ have certainly made a positive contribution to this process by assessing recent reports of the causes of the disaster, paying particular attention to the impressive argument of A.R.E. Sinclair and J.M. Fryxell ${ }^{2}$ who proposed that the contesting causes are the weather and man. Krebs and Coe single out man and his recent efforts to develop sedentary agriculture as drawing the largest portion of the blame, but 1 suggest that much of their argument is not appropriate to the highland areas of Ethiopia so severely affected by the recent famine. Furthermore, the suggestion that a return to migratory lifestyle is the most viable option is unlikely to be considered feasible in those areas of Ethiopia.

Drought is not new to Ethiopia. However, Sinclair and Fryxell ${ }^{2}$ argue that previous years of below-average rainfall did not result in the extreme mortality seen in the past 10 years. This is not the case. Ethiopia's chronicles and other historical sources reveal 23 major famines between 1540 and 1800 , with those of 1540 and 1702 receiving particular comment as to their severity ${ }^{3}$. The famine of $1828-29$ resulted in severe loss of life, and was complicated by an epidemic of cholera. The most devastating and well-described famine of 1888-92 reputedly killed one-third of the Ethiopian population ${ }^{4}$ and was complicated by a plague of locusts and an epidemic of rinderpest in cattle which almost destroyed the cattle population.

In many of the northern areas prone to cyclical drought, there is either no tradition of migration in search of pastures, water and cultivable soils or the migrations are distinct from the pastoral migrations more characteristic of other areas of Sahelian Africa. Sedentary agriculture in this area was established in the tropical highlands long before the advent of aid programmes which, along with colonization, have been proposed as major causes of the Sahelian famines ${ }^{1,2}$. Ethiopia was never colonized, with the exception of a five-year occupation by Mussolini's forces. Extensive agricultural aid programmes are a relatively recent introduction and, judging from my three years' experience in Ethiopia a decade ago, have not had the impact, penetration and consequently destruction of the environment and the ecological balance that have occurred in many other parts of Sahelian Africa. Environmental destruction has of course occurred, as a result of high population density, overgrazing, denuding of vegetation and soil erosion, but this has generally been self-inflicted and has occurred over a long time. The northern highland region of the country, also the most severely affected in the drought and famine of $1972-73$, is relatively densely populated (more than double the average population density of sub-Saharan Africa), and much of it is characterized by plateaus at an altitude of $2,500-3,000 \mathrm{~m}$, gorges, mountain peaks and deep chasms. The peasant inhabitants are engaged in sedentary subsistence farming", cultivating small plots of land, which as a result of centuries of feudal land tenure system and the traditional bequests of land, have become smaller with time. The farmers are hampered by the terrain and soil erosion occurs on an immense scale. Severe transport and communication problems associated with the rugged landscape compound their difficulties. They live, therefore, on the edge of survival.

The rainfall of the region is largely dependent on the movement of the Intertropical Convergence Zone (ITCZ) and its relation to pressure changes in the surrounding regions. Annual rainfall figures show very pronounced fluctuation from year to year, with variations of $56-140 \%$ of the mean figure reported during a 70 year period ${ }^{2}$. Failure of the rains is therefore inseparable from the man-made components of this disaster. Furthermore, whereas overgrazing in highland Ethiopia is undeniably part of the man-made contribution to the cause, it is not the result of recent settlement near waterholes as suggested by Sinclair and Fryxell ${ }^{2}$.

I submit therefore that in Ethiopia it is impossible to label the drought hypothesis as a misconception and to separate it from the alternative settlement-overgrazing hypothesis in discussion of the cause of the secular famines in that country. Furthermore, I think that broad generalizations of the Sahel which include Ethiopia should consider the geographical, historical, sociological and political factors which render it distinct from many other countries of the region.

Nevertheless, full support should be given to the recommendation of Sinclair and Fryxell that the improvement of the environment over several decades must be addressed by both developed and developing countries. The specific suggestions will require unprecedented collaboration between donor agencies and a close coordination between these agencies and the appropriate government departments in individual countries which, if to include such measures as cattle depopulation, will require a heavy hand to counteract traditional customs and practices relating to cattle keeping". (For years veterinary services have contributed to the improvement of cattle production efficiency by reducing the prevalance of many major infectious diseases but this has not been matched by corresponding improvement in livestock offtake and marketing.) But most important, the environmental improvement projects should be tailored to fit the individual countries, or in the case of Ethiopia, regions within the country, to avoid the undesirable effects of yet further inappropriate development aid such as that we are currently criticizing.

\section{Brian D. Perry \\ Virginia-Maryland Regional College of Veterinary Medicine, \\ Blacksburg, Virginia 24061, USA} \section{(1985) 1983) \\ Major groove or minor groove?}

1. Krebs. J.R. \& Coe. M.J. Nature 317,13-14 (1985)

2. Sinclair, A.R.E. \& Fryxell. J.M. Can. J. Zool. 63,987-994

Pankhurst R. J. Hist Med 21.95-124 (1966)

4. Pankhurst. R. J. Hist Med 21. 271-294 (1966)

5. Gryseels. G. \& Anderson. F.M. ILCA Res. Rep. No. 4. (International Livestock Centre for Africa. Addis Ababa

6. Perry, B.D., Mwanaumo, B., Schels. H.F. Eicher. E. \& Zaman, M.R. Prev. Vet. Med. 2. 633-653 (1984)

SIR-After Matthews first proposed that cro protein has an $\alpha$-helix that contacts the major groove of a right-handed B-DNA ${ }^{1}$, it was soon realized ${ }^{2}$ that the helix-major groove interaction might be a common feature by which many gene regulatory proteins recognize a particular sequence of DNA. Now we have the first crystallographic picture for this kind of binding in the studies on the phage 434 repressoroperator complex ${ }^{3}$. Although different in overall structure, endonuclease EcoRI has also been shown to have an $\alpha$-helix contacting the major groove of its substrate $^{4}$. I have suggested ${ }^{5}$ that stereochemically the major groove of $\mathrm{B}$ DNA does provide the best place for a sequence-specific DNA-binding protein to make extensive contact with a 'recognition helix' as the main determinant of specificity ${ }^{6}$. The argument is as follows ${ }^{5}$. First, the diameter of an $\alpha$-helix is at least 10.7A. Among common DNA structures, only the major groove of B-DNA is both broad and deep enough (about $11.7 \AA$ and $8.5 \AA)$ to accommodate an $\alpha$-helix. Second, the major groove is much more specific than the minor groove for protein binding. This is because any type of mutation $\quad(A-T \rightarrow T-A, \quad A-T \rightarrow$ G-C, A$\mathrm{T} \rightarrow \mathrm{C}-\mathrm{G}$ and $\mathrm{C}-\mathrm{G} \rightarrow \mathrm{G}-\mathrm{C}$ ) changes the potential hydrogen bonding pattern much less in the minor groove compared to its effect on the pattern in the major groove. An extreme example is the $\mathrm{A}-\mathrm{T} \rightarrow \mathrm{T}-\mathrm{A}$ mutation, which keeps almost the same two $\mathrm{H}$-donor positions in the minor groove but exerts a totally different hydrogen bonding pattern in the major groove. As for hydrophobic interaction, another important source of specificity, the main hydrophobic side chain (methyl 